\title{
Local knowledge production, transmission, and the importance of village leaders in a network of Tibetan pastoralists coping with environmental change
}

\author{
Kelly A. Hopping ${ }^{1,2}$, Ciren Yangzong ${ }^{3}$ and Julia A. Klein ${ }^{1,2,4}$
}

\begin{abstract}
Changing climate, social institutions, and natural resource management policies are reshaping the dynamics of socialecological systems globally, with subsistence-based communities likely to be among the most vulnerable to the impacts of global change. These communities' local ecological knowledge is increasingly recognized as a source of adaptive capacity for them as well as a crucial source of information to be incorporated into scientific understanding and policy making. We interviewed Tibetan pastoralists about their observations of environmental changes, their interpretations of the causes of these changes, and the ways in which they acquire and transmit this knowledge. We found that community members tended to agree that changing climate is driving undesirable trends in grassland and livestock health, and some also viewed changing management practices as compounding the impacts of climate change. However, those nominated by their peers as experts on traditional, pastoral knowledge observed fewer changes than did a more heterogeneous group of people who reported more ways in which the environment is changing. Herders mostly discussed these changes among themselves and particularly with village leaders, yet people who discussed environmental changes together did not necessarily hold the same knowledge of them. These results indicate that members of the community are transferring knowledge of environmental change primarily as a means for seeking adaptive solutions to it, rather than for learning from others, and that local leaders can serve as critical brokers of knowledge transfer within and beyond their communities. This highlights not only the interconnectedness of knowledge, practice, and power, but also points toward the important role that local governance can have in helping communities cope with the impacts of global change.
\end{abstract}

Key Words: cultural consensus analysis, global change; local ecological knowledge; pastoralism; social networks; Tibetan Plateau

\section{INTRODUCTION}

Global change is driving social-ecological systems outside of their historical range of conditions, thereby threatening ecosystem health and human well-being. Gradual increases in temperatures coupled with increasing climate variability and extreme events produce nonlinear and often unpredictable ecological feedbacks, which in turn interact with natural resource management practices to alter the functioning of ecosystems and social institutions (Nelson 2005, Christensen et al. 2013). Among the people most vulnerable to these changes will be those who depend directly on local ecosystems for their livelihoods (O'Brien and Leichenko 2000). Traditionally these same communities have had an intimate understanding of their environment that has allowed their long-term persistence (Berkes 2008), but when the rate of environmental change is rapid, these local knowledge systems may be unable to keep pace (Fernández-Llamazares et al. 2015). These knowledge systems are also subject to degradation by rapidly changing social institutions, such as altered land-management regulations and practices (Fernández-Giménez and Estaque 2012, Oteros-Rozas et al. 2013), participation in formal schooling (Zent 1999, Sternberg et al. 2001), and integration into the market economy (Reyes-García et al. 2007). Furthermore, if traditional knowledge of the environment becomes less accurate under altered climate regimes, people previously seen as local experts may lose credibility within their communities, and trust in local knowledge systems may be eroded (Kronik and Verner 2010). However, precisely because of the unpredictability of the local impacts of dynamic and interacting global change drivers, integrating already existing local ecological knowledge (LEK) with continuous learning and production of new LEK will be critical to subsistence-based communities' ability to cope with and adapt to their changing environments (Berkes 2009, Boillat and Berkes 2013).

Local ecological knowledge, sometimes referred to as indigenous knowledge or traditional ecological knowledge, is a complex of knowledge, practices, and beliefs concerning the biophysical environment and humans' engagement with it (Berkes 2008). Local ecological knowledge is acquired through personal observations and experiences, but it is also transmitted through social networks, including learning from elders (Reyes-García et al. 2009), participation in natural resource management institutions (Fernández-Giménez 2000), and discussion with peers (Baival and Fernández-Giménez 2012). Variation in individuals' LEK is therefore explained not only by their livelihood practices and personal characteristics (Crona and Bodin 2006, Klein et al. 2014), but also by their ability to access information through their relationships to others (Atran et al. 2002, Crona and Bodin 2006, Hopkins 2011, Isaac et al. 2014).

These networks of LEK information sharing and learning may enhance household and community resilience to the impacts of global change (Folke et al. 1998, Adger 2003, Baival and Fernández-Giménez 2012). However, power dynamics, local institutions, and government policies also affect the ability of LEK to inform climate change adaptation practices, research, and policies (Smith and Sharp 2012, Naess 2013). As environmental conditions worsen, social and political relations will become increasingly important for maintaining system functioning under

${ }^{1}$ Graduate Degree Program in Ecology, Colorado State University, ${ }^{2}$ Natural Resource Ecology Laboratory, Colorado State University, ${ }^{3}$ Geography Department, Tibet University, ${ }^{4}$ Department of Ecosystem Science and Sustainability, Colorado State University 
the pressures of environmental change (Salick and Ross 2009). When there is little support from central governments or when policies create additional vulnerability, strong links within locallevel social networks can increase a community's ability to cope with the impacts of change (Adger 2003). The structure of these networks therefore shapes not only processes of learning LEK, but also strategies of resource use, conflict adjudication, and coordination to take collective action (Adger 2003, Crona and Bodin 2006, Ingty and Bawa 2012, Isaac et al. 2014).

The Tibetan Plateau exemplifies a social-ecological system facing a host of interacting social, political, and environmental changes that threaten its resilience, including the maintenance and ongoing development of LEK. Pastoralists have been herding livestock in Tibet for millennia, which has allowed communities to develop a reservoir of LEK that integrates both practical and cosmological concerns (Huber and Pedersen 1997, Byg and Salick 2009, Fu et al. 2012, Salick et al. 2012, Klein et al. 2014). However, significant climate warming along with changes in the timing and variability of precipitation (Kang et al. 2010, Christensen et al. 2013) are affecting ecosystem functioning (Klein et al. 2007, Wang et al. 2012). New rangeland policies are altering pastoralists' management of their herds and pastures (Yangzong 2006, Bauer and Nyima 2010, Klein et al. 2011, Cao et al. 2013). Increasing school enrollment and participation in off-range wage labor will likely decouple young, rural Tibetans from close engagement with the land (Fischer 2011, Iselin 2011), limit their ability to learn from elders, and thus present additional ways by which LEK could be lost (Zent 1999, Sternberg et al. 2001, Reyes-García et al. 2007, 2010).

Local ecological knowledge is an especially important resource for understanding and responding to the impacts of global change in systems like Tibet, in which political and biophysical constraints limit livelihood, natural resource management, and governance options (Fu et al. 2012). The erosion of Tibetans' LEK, without replacement by the production of new knowledge suited to new circumstances, could reduce local capacity to cope with environmental changes and have cascading effects for ecosystem health and the provision of ecosystem services. Loss of LEK also represents a missed opportunity for pastoralists' knowledge to inform and improve regional climate adaptation policies and western scientific understandings of the ways in which this remote system is being affected by global change (Homann et al. 2008, Reid et al. 2009, Chaudhary and Bawa 2011, Bawa and Ingty 2012, Fu et al. 2012, Laborde et al. 2012, Oba 2012, Smith and Sharp 2012, Klein et al. 2014).

With rapid social and environmental change occurring in communities around the world, it is critical to move beyond focusing only on the content of LEK to also incorporate a better understanding of the processes by which LEK is produced, transmitted, and used (Zarger and Stepp 2004, Berkes 2009, Naess 2013). Therefore, with this study we interviewed 48 pastoralists from a village in central Tibet to examine three sets of questions:

1. What environmental changes do pastoralists observe, and what are their perceptions of the drivers of these changes?

2. How is this knowledge of environmental change acquired and shared, and what are the factors that influence these processes?
3. Does sharing knowledge of environmental change facilitate learning, and is it likely to contribute to the community's ability to cope with these changes now and in the future?

To address the first question, we used cultural consensus analysis (Romney et al. 1986) to determine the environmental changes agreed upon by this community, while also examining knowledge held by subgroups within the village. We then took an ethnographic approach to understanding their explanations for the drivers of these changes (Corbin and Strauss 1990, Strauss and Corbin 1998). To address the second and third questions, we used qualitative and social network analyses to determine how community members learn about LEK and seek out others to discuss the changes they observe (Freeman 1979, Gould and Fernandez 1989, Bodin et al. 2006). Regression models indicated which demographic and livelihood factors contribute to people's positions in the social network. We discuss our results in terms of how they may be useful in dialogue with western scientific knowledge, informative for management decisions regarding Tibetan rangelands, and, ultimately, their implications for the continued resilience of Tibetan pastoral communities and other social-ecological systems under global change.

\section{METHODS}

\section{Study area}

We conducted this research in one natural village, the smallest administrative settlement unit in Tibet, in Damzhung County in the Tibet Autonomous Region of China. It is one of six natural villages ("rukhag") within an administrative village ("rangbyug grongtsho") that covers approximately $600 \mathrm{~km}^{2}$, has an average elevation of 5000 meters above sea level, and spans alpine meadow and alpine steppe vegetation types. Administrative villages are the second smallest settlement unit and the highest organizational level at which leaders are selected by villagers, rather than appointed by higher officials. Each natural village has one leader and one representative to the administrative village committee, both of whom are also selected by villagers. Livestock herding is the primary livelihood practice, and children begin assisting their parents with herding at an early age. At the time of our interviews, this natural village had 38 households with 179 people and 3538 head of livestock, including yaks, sheep, goats, and horses, which comprised $65 \%, 28 \%, 5 \%$, and $2 \%$ of the total sheep equivalent units (SEU) in the village, respectively. Engagement in off-range, income-generating activities is becoming increasingly prevalent, primarily because of the village's proximity to a site sacred to Tibetan Buddhists, which has been promoted as a tourist destination since the 1990s. This has created year-round and seasonal service-oriented economic opportunities for some households. The majority of adults in the village never attended school, but reforms in 2007 made nine years of schooling compulsory for all children.

Recent national- and provincial-level policies have also affected mobility and herd sizes in the study village (Bauer and Nyima 2010). In 2005, Han Chinese government officials mandated the fencing of wetlands and established fixed territories for each village in the study area. The construction of fences between villages in 2008 further demarcated their boundaries. Households continue to make four longer-distance migrations per year, in addition to shorter, daily movements. The fences hinder 
movement for some who would like to move further with their herds into the mountains, whereas for others they reduce daily labor by allowing livestock to stay penned in the wetlands with less supervision. Herd sizes were capped at 40 sheep equivalent units per person (SEU) in 2005 and were lowered in 2011 by changing the SEU conversion rate for yaks.

\section{Interviews}

In 2012, we conducted structured interviews about environmental change with 48 people, who represented approximately $40 \%$ of the adult villagers. Interviews were conducted in Tibetan by a native speaker after informed consent was received. We attempted to interview all available adults in the village, but, as in other studies asking pastoralists about environmental change, many women opted out of the interviews, usually citing that they did not know how to answer our questions because they were not the primary herders in their households (Fernández-Giménez and Estaque 2012, Oteros-Rozas et al. 2013, Klein et al. 2014).

We interviewed 39 men and 9 women from 28 households in the natural village. Their ages ranged from 18 to 72 (mean: 41 years). Half were heads of their household. Three held official leadership positions at the natural and administrative village levels: one was the natural village leader, one had previously been the natural village leader for 29 years and was currently serving as representative to the administrative village committee, and one was the deputy administrative village leader. In addition, six others had served in leadership positions in the past. The majority $(60 \%)$ spend most or all of their time herding livestock, whereas the others herd seasonally or not at all while they pursue off-range economic opportunities. Although women in this community also herd livestock, their daily activities are usually closer to home and include milking and caring for livestock.

We asked open-ended questions about people's ways of learning about the environment, the changes they had observed in different climatic and ecological variables over their lifetimes, and the reasons for why these environmental changes are occurring. For 50 questions about specific environmental changes, we followed the closed-ended format used by Klein et al. (2014), in which responses could be "increase/no change/decrease," or "earlier/no change/later." Enough people responded instead that aspects of the environment vary interannually, depending on rainfall, that we subsequently added "it depends on rain" as another response option. We also asked them to name the people within their household and village who they viewed as experts about the climate, grassland, and livestock, to describe the type of LEK typically held by women and by men, and, following the question format for information exchange used by Crona and Bodin (2006), to free list the people with whom they talk about the environmental changes they observe.

\section{Data analysis}

Knowledge of environmental change

To determine the environmental change trends on which the community agreed most, we used cultural consensus analysis (CCA), a type of factor analysis used to identify whether a group of people share a common understanding about a particular topic, and if so, the culturally appropriate responses within this group to a set of questions about the topic (Romney et al. 1986,
1987, Weller 2007). The CCA starts with the premise that if interviewees are part of the same culture, meaning that they share beliefs and mental constructs about the world, then there will be an underlying set of responses about a given topic that are true, or correct, for this group, despite some level of heterogeneity in their beliefs (Romney et al. 1986, D’Andrade 1987). When most of the variation in people's responses can be explained by a single factor in the CCA, i.e., when the ratio of the first to second eigenvalue is greater than three, this indicates that interviewees are sharing a cohesive understanding of the topic, and the analysis can proceed to identify "culturally correct" responses for the group (Romney et al. 1987, Weller 2007).

The CCA determines "correct" answers by first comparing each interviewee's answers across all questions to all other interviewees' answers. Those who share more identical responses with others are given higher "competence" scores, reflecting their greater degree of agreement with the dominant views of the group. Then, when determining the group's culturally correct response for each question, interviewees' answers are weighted by their competence scores to decrease the influence of idiosyncratic responses in the data. This helps minimize the influence of interviewees' guesses and the random responses assigned by researchers to avoid missing values in the CCA, but it may also obscure specialized knowledge held by a minority of community members. Although CCA takes a simplifying approach to culture and knowledge heterogeneity, it is nonetheless a useful tool for revealing aspects of knowledge on which people agree most, including perceptions of environmental change (Crona et al. 2013, Carothers et al. 2014, Klein et al. 2014).

We coded responses to the 50 multiple-choice questions about environmental change as -1 for "decreasing" and "earlier," 0 for "no change," and 1 for "increasing" and "later." When people responded that an environmental change "depends on rain," meaning that it varies with the weather each year, we coded these as "no change" for the CCA. We took this approach because interviewees who used this response seemed only to be linking it to interannual fluctuations, rather than to longer-term change trends. To further justify the decision to treat "it depends on rain" as a "no directional change" response, we tested whether people who reported that things depend on rain also tended to report changes in rainfall itself. We found that the frequency of "depends on rain" responses differed significantly among people who reported "no change," "increasing," "decreasing," or "don't know" for rainfall trends $\left(\chi^{2}=9.78, \mathrm{df}=3, \mathrm{p}=0.02\right)$. People who said that they didn't know about changes in rainfall gave the most "depends on rain" responses to other questions, particularly in comparison to people who reported decreases in rainfall (pairwise comparison: $\mathrm{p}=0.06$ ). Therefore, when people only said that an aspect of the environment depended on rain, we interpreted this to mean that they were not observing a longer-term change trend. However, in subsequent analyses we include the "depends on rain" responses to gain a more nuanced understanding of ecosystem dynamics and LEK.

To meet the assumptions of CCA, we removed questions and interviewees so that no interviewee had "don't know" or missing responses to more than $10 \%$ of the questions (Miller et al. 2004). For the remaining few missing responses, we assigned answers 
randomly (Weller 2007). This left 30 questions and 31 interviewees in the analysis, meeting the recommendation to have at least 30 people for CCA (Weller 2007). This is derived from calculations showing that when interviewees agree on $50 \%$ or more of their responses (mean competence score $\geq 0.50$ ), then at least 29 people will be needed to accurately identify "correct" responses for $99 \%$ of the questions at a 0.95 confidence level (Romney et al. 1986). We performed the CCA in Ucinet with the ordinal data model option (v. 6.507, Borgatti et al. 2002). The output showed that the ratio of the first to second eigenvalue was 5.15 , indicating that the data met the conditions for finding consensus around a single set of environmental changes. Interviewees' mean competence score was 0.57 , so the sample size of 31 was sufficient to detect the environmental changes on which this community agreed most.

To move beyond the consensus view, we also tested whether subgroups of people tended to respond more similarly to each other than to the community as a whole when asked about environmental changes. First we created a Gower dissimilarity matrix for nominal variables that compared responses among all interviewees who had answered all 50 questions $(n=45)$. For this we allowed "don't know" and "depends on rain" responses to remain in the data. Next we performed a cluster analysis on the dissimilarity matrix and used the Ward clustering algorithm to minimize within-group variance in responses while maximizing between-group variance (McCune et al. 2002). We used the pseudo-t statistic to determine the cut-off point at six clusters of people $\left(\mathrm{r}^{2}=0.40\right)$ and pairwise Wilcoxon rank sum tests to determine whether any of the resulting clusters tended to be more observant of environmental changes, as indicated by fewer "don't know" responses and more agreement on the direction of changing environmental trends. We performed the cluster analysis in SAS (v. 9.3) and Wilcoxon tests in R (v. 3.2.2, 2015).

To elucidate interviewees' understandings of causal connections among different components of the social-ecological system, we followed a grounded theory approach (Corbin and Strauss 1990, Strauss and Corbin 1998). The first author iteratively coded interview transcripts in Atlas.ti (v. 7.1.8), first using a priori codes about components of the climate and ecosystem that were the focus of the closed-ended environmental change questions, and then inductively coding other themes that emerged frequently during the interviews, such as conflict. This produced 26 codes in 4 general themes: climate, ecosystem, natural resource management, and knowledge (Appendix 1, Table A1.1). For each of the ecosystem codes, we populated the network view manager in Atlas.ti with their co-occurring climate and resource management codes and interview quotations. We then took detailed notes on these quotations, which we used to produce a web of causal relationships among aspects of the ecosystem, climate, and resource management practices, according to interviewees (Bernard 2006). To display the resulting conceptual model, we created a stylized illustration of the connections between environmental changes and drivers that were well supported by our qualitative analysis. We undertook a similar process for codes within the knowledge theme to examine interviewees' perceptions of how environmental knowledge is acquired, transmitted, and differs by gender in this community.
Transmission of environmental change knowledge in the social network

To examine with whom people share knowledge of environmental change, we created full matrices of interviewees and their directional connections, or ties, to others within and beyond the village whom they reported seeking out to discuss changes in the climate and ecosystem (Hanneman and Riddle 2005). We then analyzed the climate and ecological information networks separately. Many herders indicated that they discuss these changes with a few specific people, as well as with "all other herders they meet when out herding." The latter response was substantiated both by the frequency with which it was given and during participant observations. To differentiate those who were named specifically from those who were mentioned more generally, we assigned different weights to the ties between people. For each interviewee, we assigned the following tie weights: three to those who were named specifically; two to people who appeared to be named because they were present during the interview $(n=8)$; one to all other people in the network who were full-time herders if the interviewee responded that he talked with all other herders he met; zero to people who were not named.

To assess the degree to which people seek out (out-degree) and are sought out (in-degree) by others to discuss environmental change, we calculated Freeman degree centrality scores, using nonsymmetric, weighted ties (Freeman 1979). In-degree centrality can be robust to incomplete sampling of the entire network, making it a useful metric for our study (Costenbader and Valente 2003). Next we used brokerage measures to find people who play important structural roles in the network by connecting pairs of people who would not otherwise be linked (Hanneman and Riddle 2005, Bodin et al. 2006). We determined honest brokerage metrics by calculating the number of brokered pairs and pure brokerage scores for each interviewee (Hanneman and Riddle 2005, Sasovova et al. 2010). We also assessed the degree to which interviewees play the different brokerage roles of coordinator, gatekeeper, representative, consultant, and liaison within the social network (Gould and Fernandez 1989). Each role connects across groups of people in different ways, and can, for example, influence whether different resources users' knowledge can be shared to promote adaptive environmental management (Isaac et al. 2014).

To determine whether people who observed the same environmental changes were also more connected to each other in the social network, we calculated the density of connections for the whole network, as well as within and between the four dominant livelihood groups (mostly herding, current village leader, mostly not herding, women in the home) and the six knowledge groups produced by the cluster analysis. We tested whether any of these groups' members were more densely connected with each other than would be expected by comparing each group's internal density value to the overall network density (Hanneman and Riddle 2005, Crona and Bodin 2006). Sample variances for each group's density were generated by bootstrapping 5000 random samples from the observed network data. For density analyses, we used unweighted ties between actors to capture the degree to which all possible connections between people were actually being used. All network analyses were performed in Ucinet. 
Relationships among demographic and knowledge data

We tested for relationships between demographic variables and metrics derived from the cultural consensus, cluster, and social network analyses. We used chi-square tests to examine relationships among categorical variables, Kruskal-Wallis and Wilcoxon rank sum tests for differences among categorical variables and non-normally distributed response variables (with the Holm adjustment for multiple comparisons), and ANOVAs to test for relationships between continuous and categorical variables (with the Tukey-Kramer adjustment for multiple comparisons). We used a logistic regression to test for factors associated with being nominated as a pastoral knowledge expert, and we used multiple linear regressions to test for demographic predictors of degree centrality in the social networks. The following independent variables were included: dominant livelihood practice, daily herding distance (near vs. far), age, whether people had learned LEK from older generations, household herd diversity (Simpson diversity index; Ndikumana et al. 2000), and gender (centrality models only). Education level and literacy were negatively and positively correlated with age, respectively, and household SEU per capita were positively correlated with herding distance, so these were not included in the models. All regression analyses used stepwise model selection with a significance threshold of 0.05 for parameters to be retained. We performed statistical analyses in SAS and made figures in R (Wickham 2009) unless otherwise noted.

\section{RESULTS}

\section{Knowledge of environmental change}

\section{Consensus view of changes}

The CCA results indicate that people tend to agree on multiple indicators of alpine meadow degradation (Fig. 1a). These trends include declines in beneficial properties, such as production of the sedge Kobresia pygmaea C. B. Clarke, which is the dominant plant species and primary forage for livestock in alpine meadows. When describing alpine meadow changes, people often referred to how forage plants were not as tall as in the past, and there were fewer flowers across all species. They also strongly agreed that livestock milk production had decreased. In contrast, increasing trends were only observed for problematic elements of the system, such as the proliferation of plants that are toxic to livestock (Oxytropis glacialis Benth), lichens that form a black crust on the soil, and pikas, which many interviewees viewed as a rangeland pest.

People also tended to agree on the main climate trends (Fig. 1b). They observed that precipitation has decreased, especially in winter. They reported decreases in winter temperatures, whereas summer temperatures had increased during their lifetimes. Some disagreed with the consensus view of colder winters; as one village leader put it, "people say that many years ago, you still weren't warm enough wearing a lokpa [traditional sheep-skin robe]. Now you can be warm enough wearing Han Chinese clothes [that are less insulating]. So it must be warmer now than a long time ago." Consistent with summer warming trends, people observed decreasing snow on permanently snow-covered mountains, which have a distinct term in Tibetan, "gangs ri." Responses were nearly unanimous about rising water levels in the closed-basin lake. Although some recalled that the lake had started rising as early as the 1960 s and 1970 s, many reported relatively recent, rapid changes, such as newly constructed fences becoming submerged by the lake. One man said: "In the beginning I put prayer flags close to the water, but they were covered more and more every year. I moved them higher, and they were covered again."

Fig. 1. Predominant observations of (a) alpine meadow and (b) climate trends from the cultural consensus analysis (CCA). Scores closer to 1 indicate strong consensus on an increasing trend, scores closer to -1 indicate strong consensus on a decreasing trend, and scores closer to zero indicate either observations of "no change" or a mix of "increase" and "decrease" responses.
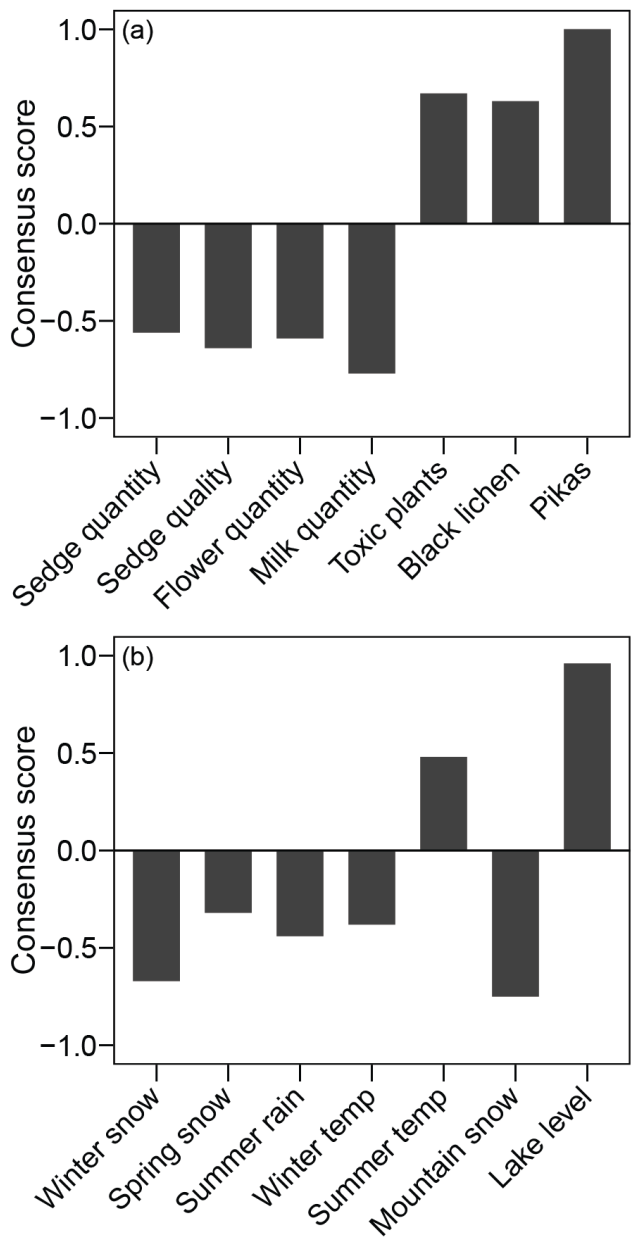

\section{Drivers of ecological change}

Interviewees attributed the grassland changes they observed to the impacts of changing climate, but they viewed decreasing livestock health as a result of both environmental changes and changing land management practices (Fig. 2). They described how the quality, quantity, and phenology of plants and the timing of livestock milk production all depend on the weather. Interviewees overwhelmingly attributed declining meadow and wetland health to decreasing precipitation. Overall, they said that less rainfall is responsible for decreases in flowers, medicinal and edible plants, and shorter heights of the dominant plant species, 
Fig. 2. Conceptual model of the drivers and consequences of environmental changes, according to interviewees. Arrows with solid lines represent promoting relationships between system components, and arrows with dashed lines represent inhibiting relationships. Pluses indicate increasing trends, and minuses indicate decreasing trends. In the case of decreasing snow on permanently snow-covered mountains (gangs ri), it is the resulting snowmelt that is responsible for promoting the increase in lake level.

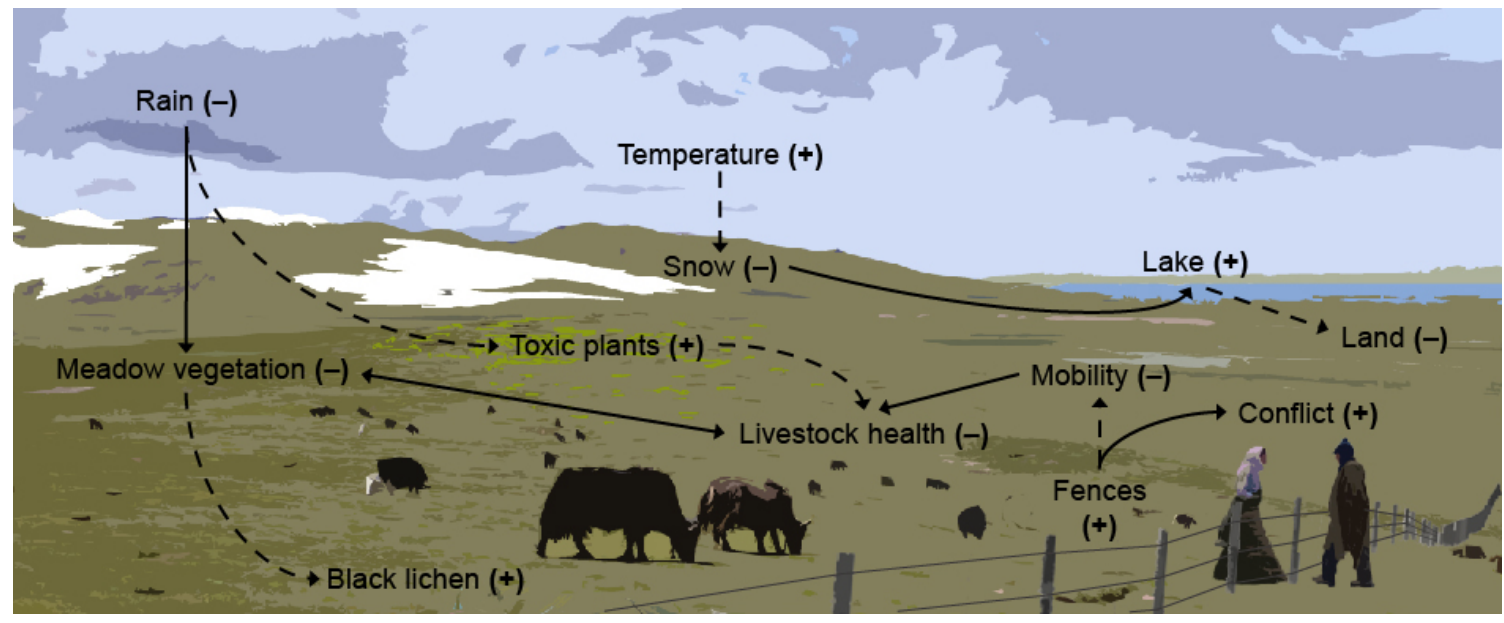

K. pygmaea. When lack of rain causes plants to die, lichen takes their place, forming a crust over exposed soil and dead root-mats. Toxic plants ( $O$. glacialis) respond positively to drier conditions. People consistently listed $O$. glacialis, a type of locoweed (Lu et al. 2014), as the worst type of plant, and the local traditional animal doctor estimated that $10 \%$ of the village's livestock die each year from eating $O$. glacialis. The many undesirable effects of reduced precipitation led one herder to comment: "If the grassland continues to degrade, then we will have to change our livelihoods. But if we have good rain, then this could reverse."

Rather than linking changing temperatures to vegetation directly, people primarily connected temperature change to increasing snowmelt in the mountains. A subset of people also identified how increased mountain snowmelt runs off into the closed lake basin, causing the lake to rise and inundate meadow and wetland pastures. Thus, interviewees view precipitation as directly affecting the quality and quantity of vegetation, whereas temperature indirectly affects the spatial extent of the grassland.

People more frequently described bottom-up effects of the grassland condition on livestock than top-down effects of grazing on the grassland. They agreed that livestock health, body size, and milk production are decreasing, and they mainly attributed these declines to insufficient access to meadow and wetland forage and increases in toxic plants and livestock parasites. In addition to the role of weather in driving reductions in forage availability, some people also mentioned competition for forage among growing livestock populations as well as between livestock and pikas. One older man said: "Many years ago, because there weren't as many livestock, livestock could choose the best grassland to eat. Now they can only eat to fill their stomachs, but they can't choose the best quality [plants]." Fences that restrict livestock mobility were often cited as being bad for livestock because they limit their ability to move and graze freely. Conversely, some said that fences are good because they encourage people to care for the land.
Although interviewees' views on the relationships between the grassland, livestock, and management practices were more mixed than their understanding of climate-grassland relationships, people were nearly unanimous in their concern that fences are creating conflicts over access to grazing land, which had not been a problem before the grassland reform. These conflicts primarily arise between people from different villages when livestock graze others' land during their seasonal migrations. They also anticipate that fences will hinder their ability to move their livestock to snowfree areas during severe snowstorms, which was an important coping strategy in the past (Yeh et al. 2014).

A few older people (mean age: 52 years) invoked cosmological explanations for the changes they observed. Smaller body size of animals and declining soil quality were cited as specific markers of the coming of the end of the world. They attributed the impetus for this decline to increased human and livestock populations, the presence of electricity and non-Tibetan people in Tibet, and desecration of sacred mountains by mining and of the sacred lake by swimming and washing in it.

\section{Knowledge subgroups}

Although the CCA results indicate the environmental changes on which the community agreed most strongly overall, heterogeneity in interviewees' responses may be explained by the existence of subgroups of people who hold different knowledge from the consensus view. First, we briefly examined whether men and women are perceived to hold different LEK in this community. Next, we identified who are regarded by their peers as experts on pastoral knowledge. Finally, we determined whether other individuals emerge as particularly observant of environmental changes based on responses to closed-ended questions, and we examined the additional insights they provided.

When asked about gender differences in LEK, men and women alike agreed that men know more about everything related to the climate and grassland, though women know more about caring for livestock. Indeed, we found that men were often unable to 
Table 1. Description of the six knowledge clusters determined by observations of environmental changes. Names are assigned to groups based on their defining feature, some of which are described under the social network results. Dominant responses were given significantly more by one group than by others across all environmental change questions.

\begin{tabular}{|c|c|c|c|c|c|c|c|c|}
\hline & \multicolumn{6}{|c|}{ Knowledge Group } & \multicolumn{2}{|c|}{ Group Differences } \\
\hline & A: Observant & $\begin{array}{c}\text { B: } \\
\text { Younger }\end{array}$ & C: Connected & D: Neighbors & $\begin{array}{c}\text { E: Depends on } \\
\text { rain }\end{array}$ & $\begin{array}{c}\text { F: } \\
\text { Older }\end{array}$ & Test statistic & $\mathrm{p}$-value \\
\hline $\begin{array}{l}\text { Number of } \\
\text { members }\end{array}$ & 8 & 9 & 7 & 7 & 5 & 9 & & \\
\hline Mean age (range) & $\begin{array}{c}39.3 \\
(23-57)\end{array}$ & $\begin{array}{c}31.1 \\
(18-47)\end{array}$ & $\begin{array}{c}41.6 \\
(32-67)\end{array}$ & $\begin{array}{c}48.6 \\
(29-72)\end{array}$ & $\begin{array}{c}38.2 \\
(27-59)\end{array}$ & $\begin{array}{c}49.8 \\
(33-61)\end{array}$ & $\mathrm{F}_{5,39}=2.20$ & $\mathrm{p}=0.07$ \\
\hline $\begin{array}{l}\text { Number of current, } \\
\text { former leaders }\end{array}$ & 1,0 & 0,0 & 0,0 & 0,2 & 1,0 & 1,3 & $\chi^{2}{ }_{5}=14.21$ & $\mathrm{p}=0.16$ \\
\hline Number of experts & 1 & 1 & 1 & 2 & 0 & 1 & $\chi_{5}^{2}=1.93$ & $p=0.86$ \\
\hline $\begin{array}{l}\text { Number of full- } \\
\text { time herders }\end{array}$ & $5(63 \%)$ & $4(44 \%)$ & $4(57 \%)$ & $5(71 \%)$ & $2(40 \%)$ & $6(67 \%)$ & $\chi^{2}{ }_{5}^{5}=2.69$ & $\mathrm{p}=0.75$ \\
\hline Number of women & $2(25 \%)$ & $1(11 \%)$ & $2(29 \%)$ & 0 & $2(40 \%)$ & 0 & $x_{5}^{2}=6.80$ & $\mathrm{p}=0.24$ \\
\hline Dominant response & $\begin{array}{c}\text { Decrease / } \\
\text { Later }\end{array}$ & Don't know & Mixed & No change & $\begin{array}{l}\text { Depends on } \\
\text { rain }\end{array}$ & No change & & \\
\hline
\end{tabular}

answer questions about changes in livestock milk production and tended to defer to women in the household, whereas women often said that they could only answer these milk-related questions. One herder, who made frequent reference to the LEK he had learned from his father, explained another dimension of these gender differences beyond household labor division: "If you have lots of traditional customs and observations, then you must teach your sons. Daughters get married and leave the family, so the family knowledge must be passed on to the sons."

When interviewees were asked to name those who know the most about the climate, grassland, and livestock, 10 men were nominated by at least 1 person outside of their household. In subsequent descriptions, we therefore use the term "peernominated expert" or simply "expert" to refer to these people regarded as being exceptionally knowledgeable about pastoral LEK. Three of the men were current village leaders, six were fulltime herders, and one was an elderly man no longer actively engaged in herding. Because of the unique role that current village leaders play in the social network, we removed them from all subsequent analyses on the remaining seven peer-nominated experts to avoid confounding interpretation of results. However, the following significant predictors of expert status remained the same whether the current leaders were included or excluded from the regression. The experts tend to move longer distances daily with their livestock $\left(\chi^{2}=6.80, \mathrm{df}=1, \mathrm{p}=0.009\right)$ and are significantly older $\left(\chi^{2}=5.54, \mathrm{df}=1, \mathrm{p}=0.02\right)$ than nonexperts. The odds of someone being nominated as an expert increase by a factor of 2.9 with each 10-year increase in age. The expert group also has a significant number of people who were village leaders in the past $\left(\chi^{2}=20.72, \mathrm{df}=1, \mathrm{p}<0.0001\right)$. The experts' knowledge of environmental change was similar to the consensus view.

The similarity of interviewees' responses across 50 environmental change questions produced 6 knowledge subgroups, or clusters, within the community (Table 1). If clusters contain people who gave more "don't know," "no change," or "depends on rain" responses, this indicates that they may be less observant of longerterm environmental trends than clusters of people who gave more "increase," "earlier," “decrease," and "later" responses. This does not negate that people who often responded that things were "not changing" or "depended on rain" may be knowledgeable about pastoral LEK in general; however, it does suggest that they perceive fewer long-term environmental changes. Conversely, people who report more changes are not necessarily objectively correct about their observations, but these responses do set them apart as perceiving more environmental changes than their peers. Theoretically, any of these changes could have increasing or earlier trends, but these responses were used infrequently by all interviewees, and there were no significant differences in the frequency with which any group reported these trends $\left(\chi^{2}=7.89\right.$, $\mathrm{df}=5, \mathrm{p}=0.16)$. "Decrease" and "later" responses were reported more often, and group A observed significantly more of these trends than any other group (Table 1, pairwise comparisons: $p<$ $0.05)$. On average, group A's members responded with "don't know" only $8 \%$ of the time, less than any other group, which further indicates that people in this cluster appear to be more observant of directional changes in the environment.

Group A agreed strongly about the trends detected by the consensus analysis as well as about other questions that were excluded from the CCA because there were too many other interviewees unable to answer them. For example, group A detected a suite of phenological trends that were not captured well by others, including a shortened duration of lake ice in winter and a delayed, shorter growing season in summer (Fig. 3).

\section{Production and transmission of local ecological knowledge}

Learning local ecological knowledge ( $L E K$ )

Most interviewees (64.4\%) reported learning LEK from elders in the community, saying that oral teaching is a nomad custom, and people always meet and talk about the land. They also learn from personal observations, starting in childhood when they "play in the grassland and learn on their own." However, interviewees expect that these modes of LEK acquisition will decline because children today are learning less about the environment due to being in school and generally paying less attention to the grassland. As one herder put it: "Old people have lots of experiences, and young people have good educations." Among all people in our 28 interview households $(\mathrm{n}=88$ people, including 40 children and adults who did not participate in interviews), only 
Table 2. Mean (and standard error) in- and out-degree scores, honest broker pairs, and standardized pure brokerage scores for each livelihood group in the climate and ecology social networks. Out-degree scores were log-transformed to normalize the data before performing statistical analyses. ANOVAs were used for in- and out-degree scores; Kruskal-Wallis rank sum tests were used for brokerage indices.

\begin{tabular}{|c|c|c|c|c|c|c|}
\hline & \multicolumn{4}{|c|}{ Livelihood Practice } & \multicolumn{2}{|c|}{ Statistical Tests } \\
\hline & Mostly herding & Current leaders & $\begin{array}{l}\text { Mostly not } \\
\text { herding }\end{array}$ & In the home & F-statistic or $\chi^{2}$ & p-value \\
\hline $\begin{array}{l}\text { Number of people } \\
\text { Climate }\end{array}$ & 27 & 3 & 12 & 6 & & \\
\hline In-degree & $7.96(0.54)$ & $31.67(1.61)$ & $3.75(0.81)$ & $2.33(1.14)$ & $F_{2}=89.10$ & $\mathrm{p}<0.0001$ \\
\hline Out-degree & $12.07(1.96)$ & $5.00(5.88)$ & $7.42(2.94)$ & $2.50(4.16)$ & $\mathrm{F}_{3,4}^{3,44}=3.78$ & $\mathrm{p}=0.02$ \\
\hline Broker pairs & $17.44(1.08)$ & $52.00(3.23)$ & $2.42(1.61)$ & $0.00(2.28)$ & $\chi^{2,44}=33.96$ & $\mathrm{p}<0.0001$ \\
\hline Pure brokerage & $0.06(0.03)$ & $0.73(0.10)$ & $0.13(0.05)$ & $0.00(0.07)$ & $\hat{\chi}^{2}{ }_{3}^{3}=13.87$ & $\mathrm{p}=0.003$ \\
\hline Ecology & & & & & & \\
\hline In-degree & $8.96(0.52)$ & $34.00(1.55)$ & $3.58(0.78)$ & $3.17(1.10)$ & $F_{344}=111.24$ & $\mathrm{p}<0.0001$ \\
\hline Out-degree & $13.48(2.44)$ & $6.00(7.31)$ & $6.67(3.66)$ & $3.17(5.17)$ & $\mathrm{F}^{3.44}=3.52$ & $\mathrm{p}=0.02$ \\
\hline Broker pairs & $23.22(1.11)$ & $58.67(3.34)$ & $2.75(1.67)$ & $0.33(2.36)$ & $\chi^{2,34}=33.58$ & $\mathrm{p}<0.0001$ \\
\hline Pure brokerage & $0.05(0.02)$ & $0.46(0.07)$ & $0.08(0.04)$ & $0.00(0.05)$ & $\chi^{2}=14.44$ & $p=0.002$ \\
\hline
\end{tabular}

Fig. 3. Seasonal trends observed by knowledge group A, the "observant" group (black), and all others (gray). Panels (a-e) show closed-ended response options. Phenological events are arranged in order of their occurrence, starting in January and ending in September.

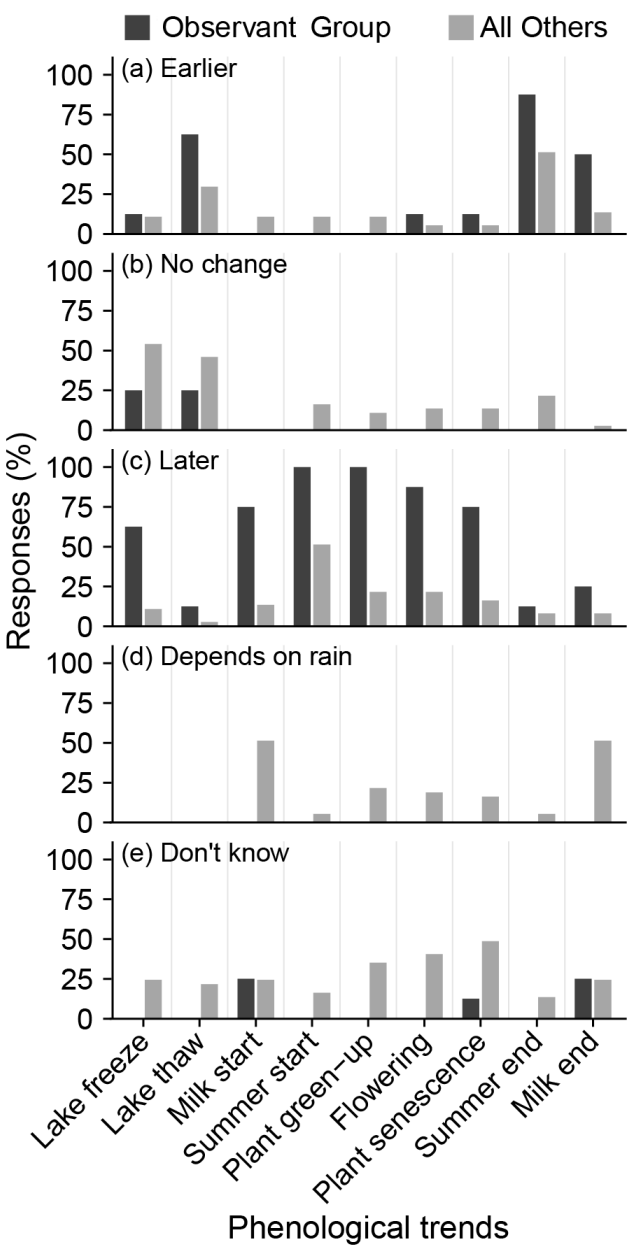

$16 \%$ of those over the age of 30 had ever attended school, and most had gone for a few months or less. In contrast, of the 23 children between 7-17 years of age in the interview households, $87 \%$ had attended at least some primary school, with several advancing beyond that. Some interviewees said that they wanted young people to return to herding eventually, but others had aspirations for them to participate in off-range livelihood activities if they were able to get a formal education. One man whose household engages only in the local tourist economy confirmed that people who already live at the sacred/tourist site, rather than herding, "don't talk about the climate and grassland anymore."

Sharing local ecological knowledge (LEK) in the social network Livelihood activity is a strong predictor of who is most sought out (in-degree) to discuss environmental changes in both the climate (full model $\mathrm{R}^{2}=0.85, \mathrm{~F}_{3,42}=86.49$; livelihood $\mathrm{p}<0.0001$ ) and ecology networks (full model $\mathrm{R}^{2}=0.88, \mathrm{~F}_{3,42}=107.22$; livelihood $\mathrm{p}<0.0001$ ). Among the four livelihood groups, current village leaders are significantly more sought out than anyone else, followed by full-time herders, who are significantly more sought out than people who are mostly not herding and women who tend to stay at home (Table 2). Peer-nominated experts are also more sought out than nonexperts (climate network $\mathrm{F}_{1,43}=18.29, \mathrm{p}=$ 0.0001 ; ecology network $\mathrm{F}_{1,43}=6.17, \mathrm{p}=0.02$ ).

Demographic variables are less able to predict the degree to which people seek out others (out-degree) in the climate $\left(\mathrm{R}^{2}=0.24\right.$, $\left.\mathrm{F}_{4,41}=4.61\right)$ and ecology networks $\left(\mathrm{R}^{2}=0.12, \mathrm{~F}_{3,42}=2.99\right)$. The most significant predictor was that people who learned LEK from older generations sought out more people to discuss climate changes $(p=0.008)$. Livelihood practice was also significant in both the climate $(p=0.03)$ and ecology networks $(p=0.04)$, with full-time herders seeking out significantly more people than nonherders and women (Table 2). Status as a peer-nominated expert was not a significant predictor of out-degree scores.

Because of the high degree to which village leaders are sought out in the climate and ecology networks, they broker significantly more pairs of otherwise unconnected people than any other livelihood group, giving them significantly higher pure brokerage 
Table 3. Density of connections within and between primary livelihood groups in the ecology network. Values indicate the density of connections from people in each row seeking out people in each column. T-tests on bootstrapped data compare within-group density to the whole-network density of 0.114 . The only between-group density that is significantly higher than the whole-network density is full-time herders' connection to village leaders $(\mathrm{z}=4.12, \mathrm{p}<0.001)$.

\begin{tabular}{|c|c|c|c|c|c|c|c|}
\hline & \multirow[b]{2}{*}{$\mathrm{n}$} & \multicolumn{4}{|c|}{ Livelihood Practice } & \multicolumn{2}{|c|}{ T-test } \\
\hline & & $\begin{array}{l}\text { Mostly } \\
\text { herding }\end{array}$ & $\begin{array}{l}\text { Current } \\
\text { leaders }\end{array}$ & $\begin{array}{l}\text { Mostly not } \\
\text { herding }\end{array}$ & In the home & Z-score & $\mathrm{p}$-value \\
\hline Mostly herding & 27 & 0.234 & 0.284 & 0.04 & 0.037 & $z=1.66$ & $\mathrm{p}=0.05$ \\
\hline Current leaders & 3 & 0.012 & 0.833 & 0 & 0 & $z=2.75$ & $\mathrm{p}<0.001$ \\
\hline Mostly not herding & 12 & 0.09 & 0.139 & 0.038 & 0 & $z=-2.54$ & $\mathrm{p}<0.001$ \\
\hline In the home & 6 & 0.019 & 0.056 & 0.014 & 0.033 & $z=-1.96$ & $\mathrm{p}<0.001$ \\
\hline
\end{tabular}

scores (Table 2). On average, the only types of brokers that differ significantly among livelihood types are gatekeepers (climate network: $\chi^{2}=8.93, \mathrm{df}=3, \mathrm{p}=0.03$; ecology network: $\chi^{2}=13.40$, $\mathrm{df}=3, \mathrm{p}=0.003$ ) and representatives (Fig. 4 ; climate network: $\chi^{2}$ $=11.93, \mathrm{df}=3, \mathrm{p}=0.008$; ecology network: $\chi^{2}=13.80, \mathrm{df}=3, \mathrm{p}$ $=0.003$ ). Significantly more herders serve as representatives in both networks because of the way that they link other herders to village leaders (Fig. 4). Village leaders serve as gatekeepers significantly more than members of other livelihood groups because of the way they connect herders who seek them out to the other village leaders with whom they themselves discuss environmental change issues (Fig. 4). However, in the climate network, only the two administrative village leaders are strong gatekeepers, whereas the natural village leader primarily acts as a liaison between herders and nonherders. In the ecology network, the natural village leader is a consultant, connecting herders to other herders, as well as a gatekeeper, connecting herders and nonherders to leaders.

The six knowledge clusters were not significantly different in their honest brokerage metrics, the degree to which their members are sought out by others in the climate or ecology networks, nor for how much they seek out others in the climate network. However, in the ecology network, people in the observant group (A) seek out significantly more people than do those in the youngest group $\left(\mathrm{B} ; \mathrm{F}_{5,39}=2.79, \mathrm{p}=0.03\right)$.

Overall, centrality scores show that village leaders, full-time herders, peer-nominated experts, people who learned LEK from elders, and members of the observant group (A) are more central to the network because of their higher degree of connection to others (Fig. 5). Notably, former village leaders, unlike current village leaders, are not significantly more sought out than people who had never been leaders. Women tend to be more peripheral to the core structure of the network. This is partly an artifact of our inability to interview as many women as men, but is also due to women seeking out only 1.4 people on average to discuss environmental changes, versus men seeking out 7.2 people on average. Furthermore, of the people who said they seek out others, $83 \%$ of women but only $41 \%$ of men named members of their own household.

\section{Linking knowledge sharing with knowledge holding}

If knowledge of environmental change is acquired through discussions of these changes with others, then we would expect people who hold similar LEK to be more densely connected in the social network. To test this, we compared the density of connections within and between the six knowledge clusters as well as within and between the four livelihood groups. Within- and between-group densities indicate the extent to which all of the possible connections are actually made between people in the network. The whole-network densities and subsequent results are not significantly different between the climate and ecology networks $(\mathrm{t}=-1.35, \mathrm{p}=0.16)$, so we only report results for the ecology network.

Densities show that herders talk more among themselves than with nonherders and that they also seek out the village leaders at higher rates than any other livelihood group does (Table 3 ). The density of connections among herders, among village leaders, and between herders and village leaders are significantly higher than the average density of connections throughout the whole network. People who are not primarily engaged in herding activities and women who tend to stay in the home are less densely connected among themselves and with others in the network. There are no significant trends in the density of connections for peernominated experts.

In contrast to the differences between livelihood groups, there are few differences in density among the knowledge groups (Table 4). Only group $\mathrm{C}$ has marginally significantly more connections among its members than would be expected based on the density of the whole network. Furthermore, several knowledge groups' members are more densely connected to members of other groups than to members of their own. This demonstrates that although people in the knowledge groups have, by definition, tended to observe the same environmental changes as each other, they discuss these issues across knowledge groups.

\section{DISCUSSION}

\section{Integrating knowledge sources to understand environmental change in central Tibet}

Being well attuned to the environment has allowed Tibetan pastoralists to sustain their livelihoods under dynamic and extreme climatic conditions for millennia, and their LEK will likely be key to their continued resilience under global change. Because herders are keenly aware of the environmental trends that have the strongest effect on their daily lives, the changes for which they have a high degree of consensus and concern may also point toward under-studied trends and maladaptive policies that threaten social-ecological resilience. Their LEK is thus poised 
Table 4. Density of connections within and between knowledge groups in the ecology network. Values indicate the density of connections from people in each row seeking out people in each column. T-tests on bootstrapped data compare within-group density to the wholenetwork density of 0.114. (Group A: observant, Group B: younger, Group C: connected, Group D: neighbors, Group E: depends on rain, Group F: older)

\begin{tabular}{|c|c|c|c|c|c|c|c|c|c|}
\hline & \multirow[b]{2}{*}{$\mathrm{n}$} & \multicolumn{6}{|c|}{ Knowledge Group } & \multicolumn{2}{|c|}{ T-test } \\
\hline & & A & B & $\mathrm{C}$ & $\mathrm{D}$ & $\mathrm{E}$ & $\mathrm{F}$ & Z-score & p-value \\
\hline Group A & 8 & 0.143 & 0.069 & 0.161 & 0.125 & 0.125 & 0.139 & $z=0.41$ & $\mathrm{p}=0.36$ \\
\hline Group B & 9 & 0.083 & 0.069 & 0.095 & 0.095 & 0.067 & 0.086 & $z=-0.78$ & $\mathrm{p}=0.65$ \\
\hline Group C & 7 & 0.232 & 0.127 & 0.310 & 0.204 & 0.171 & 0.254 & $z=1.62$ & $\mathrm{p}=0.05$ \\
\hline Group D & 7 & 0.036 & 0.048 & 0 & 0.119 & 0.029 & 0 & $z=0.07$ & $\mathrm{p}=0.40$ \\
\hline Group E & 5 & 0.175 & 0.089 & 0.171 & 0.143 & 0.10 & 0.20 & $z=-0.17$ & $\mathrm{p}=0.50$ \\
\hline Group F & 9 & 0.194 & 0.099 & 0.19 & 0.159 & 0.222 & 0.181 & $z=0.54$ & $\mathrm{p}=0.28$ \\
\hline
\end{tabular}

Fig. 4. Mean ( $\pm \mathrm{SE})$ normalized brokerage scores for different brokerage roles in the ecology network, averaged by livelihood type. Brokers who are coordinators connect otherwise unconnected pairs of people from the same livelihood group as the broker (e.g., a herder connects two other herders to each other in the network). Gatekeepers connect a person from a different group to his or her own group (e.g., a village leader connects a herder to another village leader). Representatives connect a person from the same group to a person from a different group (e.g., a herder connects another herder to a village leader). Consultants connect people from the same group as each other, but not as the broker (e.g., a village leader connects two herders to each other). Liaisons connect a person from one group to a person in a third group (e.g., a village leader connects a herder to a nonherder). In this network, there are significant differences among livelihood groups for gatekeepers $(p=0.0004)$ and representatives $(p=0.003)$.

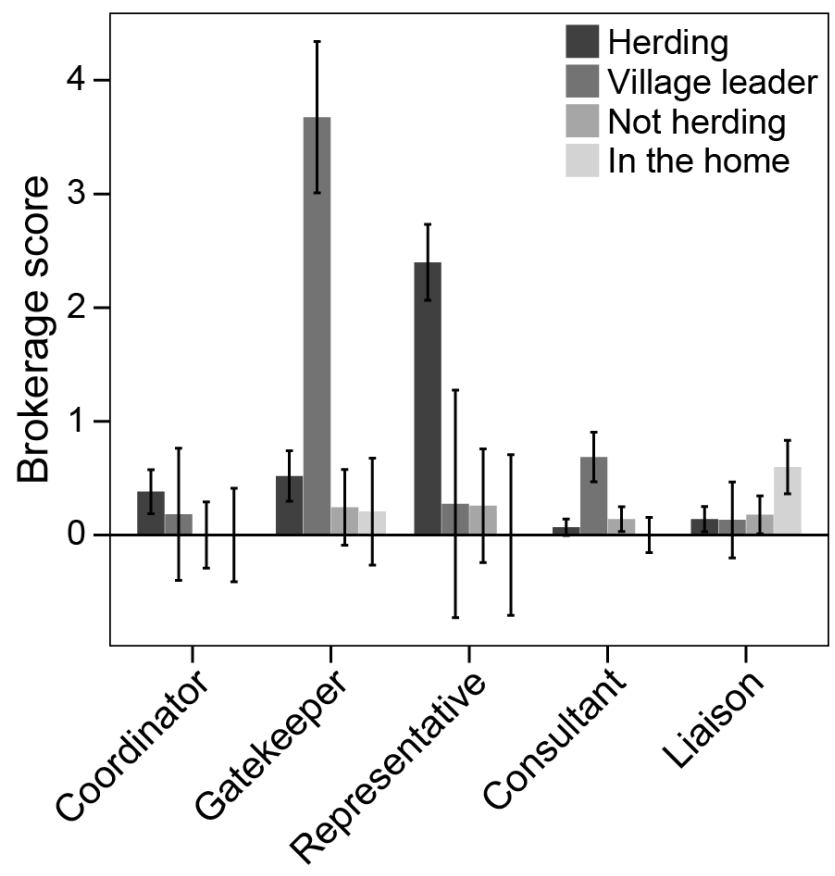

Fig. 5. Social network of interviewees and others with whom they talk about climate and ecological changes. Nodes represent individuals, and arrows indicate directional connections between people. Squares show people nominated by their peers as pastoral local ecological experts (LEK) experts. Larger nodes are members of the "observant" group, and color is scaled from people who herd full time (dark) to men who spend little time herding and women who mostly work close to home (light).

Two leaders from other villages are near the network perimeter.

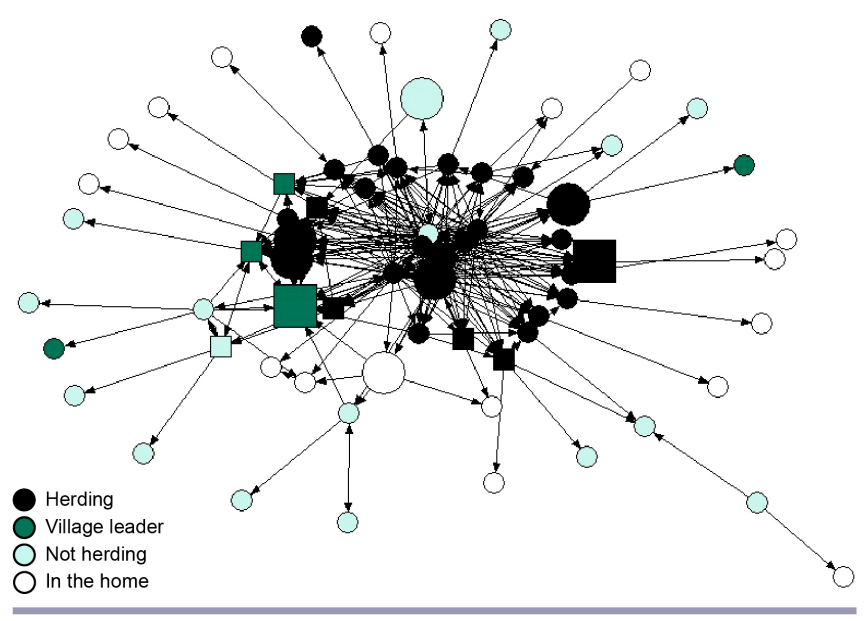

to make important contributions to our understanding of environmental change in Tibet, and it may be particularly fruitful for informing policies and decision making when brought into dialogue with western scientific knowledge (Reid et al. 2009). However, this must be done in such a way that points of divergence between the knowledge sources are used to spur further inquiry, rather than simply to validate one source against the other (Berkes 2009, Gearheard et al. 2010, Klein et al. 2014).

We found that rural Tibetans' LEK corresponds well with many aspects of western scientific knowledge of environmental change on the plateau, including rising summer temperatures, glacier melt (Kang et al. 2010, Christensen et al. 2013), and the importance of precipitation for meadow functioning (Hu et al. 2013, Shi et al. 2014, Shen et al. 2015). Interviewees' LEK also contributes to the debate over the direction of phenological trends on the plateau (e.g., Yu et al. 2010, Zhang et al. 2013, Shen et al. 2015), lending 
support to the growing evidence for increasingly delayed and shortened growing seasons in central Tibet (Dorji et al. 2013, Klein et al. 2014, Zhang et al. 2015). However, herders' perceptions of colder winter temperatures and decreasing precipitation disagree with trends reported in the climate science literature (Kang et al. 2010, Christensen et al. 2013). These discrepancies may arise from the different temporal and spatial scales at which these trends are observed, and they may also be influenced by the interactions of physical, cultural, and personal factors that mediate perceptions of climate (Strauss and Orlove 2003, Klein et al. 2014). Nonetheless, LEK's strengths lie not only in identification of directional trends, but also in peoples' ability to detect complex relationships among many interacting factors (Berkes 2008). The connections that interviewees drew between decreasing rainfall and various indicators of declining grassland health suggest that drying trends could be a primary driver of ecosystem degradation in this region. For example, their knowledge of relationships between reduced precipitation, vegetation die-back, and expansion of lichen crusts calls into question the western scientific assumption that increasing lichen cover, an indicator of degradation, can be attributed solely to overgrazing (Unteregelsbacher et al. 2012).

The relationship between livestock and grassland degradation is contested in the ecological literature (Harris 2010), yet regional fencing and herd reduction policies have focused on overgrazing as the main cause of degradation (Bauer and Nyima 2010). Although some interviewees acknowledged the risk of overgrazing as human populations and herd sizes grow, their concerns about the effects of mandatory fencing on interpersonal relationships and livestock health suggest that current policies are harmful to pastoral livelihoods and well-being and would thus benefit from incorporation of herders' local knowledge of sustainable rangeland management practices. In addition, fixed land allocation to households or villages may interact with aspects of environmental change in ways that are unforeseen by policy makers but clear to local residents. For example, herders' perceptions of dramatic lake level rise corroborate hydrological studies (Zhang et al. 2011), but their insights into the consequences of pasture inundation also deserve further socialecological research that can inform policy and land tenure decisions.

\section{Understanding local ecological knowledge (LEK) production and transmission}

The majority of interviewees reported learning LEK from elders, such as those who were nominated as pastoral LEK experts. These experts are likely more knowledgeable about pastoral LEK because of their longer time spent herding and higher degree of mobility, and they were, in fact, relatively more sought out to discuss environmental changes. However, the peer-nominated experts' knowledge of environmental change was similar to the consensus view, which suggests that although they appear to form a subgroup that is especially knowledgeable about pastoral LEK in general, they likely do not hold specialized knowledge of environmental changes beyond what is shared by the community.

As in other pastoral systems, interviewees report acquiring much of their environmental change knowledge through personal observations (Fernández-Giménez 2000, Oba 2012). This is also corroborated by our finding that members of the youngest knowledge group (B), who would have had the least time to accrue observations of change, gave the most "don't know" responses (Fernández-Llamazares et al. 2015). Moreover, the oldest groups (D and F) contain men who are no longer herding as often and are therefore not updating their knowledge of subtle changes as frequently as those who continue to herd more actively (OterosRozas et al. 2013, Klein et al. 2014). For at least a few older community members, these practice-based means of knowledge acquisition are also tempered by cosmological beliefs (Huber and Pedersen 1997, Berkes 2008, Salick et al. 2012). Our inability to interview many women and our focus on aspects of the environment considered to be more within a male domain surely omitted additional knowledge held by women. Further study of women's LEK would also likely reveal different modes of knowledge production and transmission not captured by the social network analysis reported here, in which women tend to exist at the periphery.

Overall, the dense connections within and among livelihoods groups, but not within knowledge groups, indicate that knowledge of environmental change is not primarily acquired through interactions in the social network measured here. However, the group of people who emerged as most observant of environmental change (group A) did seek out more people on average to discuss these changes. This observant group included accomplished herders, as well as a 35-year-old woman who cares for livestock during the winter and otherwise runs a small business selling goods to locals. She described how her interactions with many villagers who come to her shop have allowed her to learn about the environmental changes taking place. Although our results suggest that those who seek out more people in the network may be the most knowledgeable about environmental changes, we cannot determine the direction of causality; people may be more knowledgeable because they seek out others to learn from them, or those who are already more knowledgeable may seek out more people with whom to discuss the changes they observe.

Social network analysis is a useful tool for elucidating patterns of connection, but it can also reduce complexity and obscure other dynamics. For example, the members of knowledge group D (neighbors) were not significantly densely connected to each other, which suggests that they did not hold similar knowledge as a result of being highly connected in the network. However, five of this group's seven members are neighbors in the summer and winter pastures, and so the strength of their interpersonal relationships or the frequency with which they encounter each other to discuss these issues could be more important as a metric of knowledge transmission than the density of their connections alone. Yet, in spite of the density measures' failure to capture the importance of the quality of relationships for shaping peoples' LEK, they still indicate a unique role for village leaders in the social network.

\section{Political dimensions of global change knowledge and action}

Current village leaders emerge as brokers who connect many pairs of actors in the network of people discussing environmental changes. It is possible that interviewees who had difficulty recalling with whom they discussed changes may have defaulted to naming leaders because this was a culturally expected response (Bernard et al. 1984). However, in spite of problems with any single interviewee's recall accuracy, people who were named the 
most frequently across all interviews are likely to be the people who were most sought out in the network in reality (Bernard et al. 1982). This tendency to consult with local leaders about environmental concerns has also been reported by Mongolian pastoralists seeking ways to cope with change (Baival and Fernández-Giménez 2012).

The fact that former leaders were not disproportionately sought out within the network indicates that leaders' roles as brokers likely have more to do with their current position of power and leadership than with other traits associated with being elected as a leader. Although all current village leaders were nominated as experts about pastoral LEK, only the natural village leader was part of the observant group that appeared most perceptive of environmental changes. He also played different brokerage roles from the higher village leaders, acting as a gatekeeper between herders and other leaders, as well as serving as a consultant and liaison among villagers. Interviewees described how he encouraged them to inform him of their concerns about the changing ecosystem, and his more active engagement in the network relative to the other leaders may explain his comparatively greater knowledge of environmental changes.

Natural and administrative village leaders are responsible for local decision making, such as when to make seasonal migrations, but they also act as conduits to transmit and implement resource management decisions made by the Chinese government. As the national and provincial government increasingly extends its reach into the management of and rhetoric surrounding Tibetan rangelands, it also affects the interplay of power, knowledge, and decision making in what were historically relatively isolated parts of the plateau (Klein et al. 2011, Yeh et al. 2014). For example, provincial-level government pamphlets about overgrazing are distributed to herders via the village leader, thereby introducing a new, authoritative source of knowledge that may be at odds with herders' own LEK. The apparent authority of governmental knowledge seemed to lead some interviewees to believe that administrators should also know how to solve undesirable conditions, such as the spread of toxic plants. As herders look more toward external solutions, they may therefore seek out village leaders as their closest link to government authorities with the perceived ability to fix environmental problems.

As in other systems in which social and political changes may have more pressing impacts on local livelihoods and grassland ecosystems than the direct effects of climate change (Boillat and Berkes 2013, Boissière et al. 2013, Thébault et al. 2014), the environmental changes occurring in Tibet also have an explicitly political dimension. Due to the combined pressures of restrictive grazing policies, declining rangeland health, and growing local populations, people report having more problems with grassland management than in the past, which produces conflicts and leads them to seek out village leaders to resolve both environmental and interpersonal issues. This, along with findings from the social network analyses, leads us to conclude that herders are transferring LEK of environmental change less for purposes of learning and more with the aim of seeking adaptive solutions.

\section{Implications for the future of local ecological knowledge (LEK) and adaptive capacity}

Local ecological knowledge of past conditions provides a reservoir of practical knowledge that could prove useful in response to current and future challenges (Berkes 2009, Fernández-Giménez and Estaque 2012), but it must also be updated with new LEK relevant to changing environmental conditions (Fernández-Llamazares et al. 2015). New education requirements that remove children from the rangeland to attend boarding schools threaten their ability to continue acquiring LEK through personal observations and from elders. Whether members of this younger generation seek off-range employment or return to herding, they are less likely than in the past to hold the LEK necessary to help this system cope with the challenges posed by global change (Sternberg et al. 2001, Reyes-García et al. 2007, 2010). However, young Tibetans seeking to navigate their changing identity as contemporary pastoralists may find innovative ways to couple LEK with what they have learned in school (Iselin 2011), thereby bolstering their communities' social and environmental well-being.

The extent to which community members sought out village leaders to discuss their observations of environmental changes indicates that strong local leadership could emerge as being particularly important for improving Tibetan pastoralists' ability to cope with and adapt to the interacting pressures of social, political, and environmental changes. Interviewees sought out not only the natural village leader who encouraged them to do so, but they also proactively sought out the higher-ranking administrative village leaders to discuss environmental changes. Each of these leaders talked about ways in which they could manage the rangeland more adaptively to alleviate the stress felt by villagers, though their ability to do so is constrained by the management parameters imposed by higher levels of government. In Tibet and elsewhere, open communication between villagers and leaders who bridge administrative levels could therefore be a useful strategy for creating adaptive solutions to the environmental problems that communities face (Reid et al. 2009, Baival and Fernández-Giménez 2012, Naess 2013). However, for substantive adaptations to be possible, it is also imperative that administrators beyond the local level are receptive to LEK from village leaders and other local-level stakeholders (Fu et al. 2012).

\section{CONCLUSION}

Tibetan pastoralists hold varied knowledge of environmental changes, but they have strong consensus on trends that are most threatening to the sustainability of their livelihoods, and which thus represent key areas for further collaborative inquiry. Their environmental concerns are also entangled with land management practices and policies, which they often view as more pressing than the direct impacts of climate change alone. Overall, people primarily learn about these changes through their personal observations rather than through talking with others. Transfer of environmental change information instead appears more directed toward addressing practical challenges, with herders seeking out other herders, and community members disproportionately seeking out village leaders, to discuss the changes they face. Local leaders' ability to act as conduits for information exchange within and beyond the village thus suggests that leaders can play a key role in aggregating LEK from many peoples' observations. When possible, this knowledge can then be used to develop adaptive local resource management practices, guide scientific inquiry, and collaboratively inform policy decisions, thereby enhancing communities' resilience to the impacts of global change. 
Responses to this article can be read online at: http://www.ecologyandsociety.org/issues/responses. php/8009

\section{Acknowledgments:}

This work was supported by Graduate Research Fellowships from the Center for Collaborative Conservation and National Science Foundation awarded to K. A. H, NSF \#SBE-0624315 to J. A. K., and by open access publication funding from the Colorado State University Libraries Open Access Research and Scholarship Fund. The research was conducted under IRB protocol 11-3080H, supervised by Kathleen Galvin. This paper benefited greatly from suggestions by two anonymous reviewers. We are also grateful to Yonten Nyima and Tsechoe Dorji for their expertise during the writing of the manuscript, to Tsering Dorje for logistical support, to Kathleen Galvin, Emily Yeh, and Rick Stepp for their helpful feedback on an earlier version of this paper, and especially to the members of the Tibetan community in which this study was conducted.

\section{LITERATURE CITED}

Adger, W. N. 2003. Social capital, collective action, and adaptation to climate change. Economic Geography 79:387-404. http://dx.doi.org/10.1111/j.1944-8287.2003.tb00220.x

Atran, S., D. Medin, N. Ross, E. Lynch, V. Vapnarsky, E. U. Ek, J. Coley, C. Timura, and M. Baran. 2002. Folkecology, cultural epidemiology, and the spirit of the commons: a garden experiment in the Maya lowlands, 1991-2001. Current Anthropology 43:421-450. http://dx.doi.org/10.1086/339528

Baival, B., and M. E. Fernández-Giménez. 2012. Meaningful learning for resilience-building among Mongolian pastoralists. Nomadic Peoples 16:53-77. http://dx.doi.org/10.3167/np.2012.160205

Bauer, K., and Y. Nyima. 2010. Laws and regulations impacting the enclosure movement on the Tibetan Plateau of China. Himalaya, the Journal of the Association for Nepal and Himalayan Studies 30(1):10. [online] URL: http://digitalcommons. macalester.edu/himalaya/vol30/iss1/10/

Bawa, K. S., and T. Ingty. 2012. Climate change in Sikkim: a synthesis. Pages 413-424 in M. L. Arrawatia and S. Tambe, editors. Climate change in Sikkim: patterns, impacts and initiatives. Information and Public Relations Department, Government of Sikkim, Gangtok, India. [online] URL: http://www.sikkimforest. gov.in/climate-change-in-sikkim/climate $\% 20$ change $\% 20$ in $\% 20$ sikkim $\%$ 20-\%20patterns $\% 20$ impacts $\% 20$ and $\% 20$ initiatives.htm

Berkes, F. 2008. Sacred ecology. Second edition. Routledge, New York, New York, USA.

Berkes, F. 2009. Indigenous ways of knowing and the study of environmental change. Journal of the Royal Society of New Zealand 39:151-156. http://dx.doi.org/10.1080/03014220909510568

Bernard, H. R. 2006. Research methods in anthropology: qualitative and quantitative approaches. Fourth edition. Rowman Altamira, Lanham, Maryland, USA.

Bernard, H. R., P. Killworth, D. Kronenfeld, and L. Sailer. 1984. The problem of informant accuracy: the validity of retrospective data. Annual Review of Anthropology 13:495-517. http://dx.doi. org/10.1146/annurev.an.13.100184.002431

Bernard, H. R., P. D. Killworth, and L. Sailer. 1982. Informant accuracy in social-network data V. An experimental attempt to predict actual communication from recall data. Social Science Research 11:30-66. http://dx.doi.org/10.1016/0049-089X(82) 90006-0

Bodin, Ö., B. Crona, and H. Ernstson. 2006. Social networks in natural resource management: what is there to learn from a structural perspective? Ecology and Society 11(2):r2. [online] URL: http://www.ecologyandsociety.org/vol11/iss2/resp2/

Boillat, S., and F. Berkes. 2013. Perception and interpretation of climate change among Quechua farmers of Bolivia: indigenous knowledge as a resource for adaptive capacity. Ecology and Society 18(4):21. http://dx.doi.org/10.5751/es-05894-180421

Boissière, M., B. Locatelli, D. Sheil, M. Padmanaba, and E. Sadjudin. 2013. Local perceptions of climate variability and change in tropical forests of Papua, Indonesia. Ecology and Society 18(4):13. http://dx.doi.org/10.5751/es-05822-180413

Borgatti, S. 2002. Netdraw network visualization. Analytic Technologies, Cambridge, Massachusetts, USA.

Borgatti, S., M. Everett, and L. Freeman. 2002. Ucinet for Windows: software for social network analysis. Analytic Technologies, Cambridge, Massachusetts, USA.

Byg, A., and J. Salick. 2009. Local perspectives on a global phenomenon - climate change in Eastern Tibetan villages. Global Environmental Change 19:156-166. http://dx.doi.org/10.1016/j. gloenvcha.2009.01.010

Carothers, C., C. Brown, K. J. Moerlein, J. A. López, D. B. Andersen, and B. Retherford. 2014. Measuring perceptions of climate change in northern Alaska: pairing ethnography with cultural consensus analysis. Ecology and Society 19(4):27. http:// dx.doi.org/10.5751/es-06913-190427

Cao, J., E. T. Yeh, N. M. Holden, Y. Yang, and G. Du. 2013. The effects of enclosures and land-use contracts on rangeland degradation on the Qinghai-Tibetan plateau. Journal of Arid Environments 97:3-8. http://dx.doi.org/10.1016/j.jaridenv.2013.05.002

Chaudhary, P., and K. S. Bawa. 2011. Local perceptions of climate change validated by scientific evidence in the Himalayas. Biology Letters 7(5).http://dx.doi.org/10.1098/rsbl.2011.0269

Christensen, J. H., K. K. Kumar, E. Aldrian, S.-I. An, I. F. A. Cavalcanti, M. de Castro, W. Dong, P. Goswami, A. Hall, J. K. Kanyanga, A. Kitoh, J. Kossin, N.-C. Lau, J. Renwick, D. B. Stephenson, S.-P. Xie, and T. Zhou. 2013. Climate phenomena and their relevance for future regional climate change. Pages 1217-1308 in T. F. Stocker, D. Qin, G.-K. Plattner, M. Tignor, S. K. Allen, J. Boschung, A. Nauels, Y. Xia, V. Bex, and P. M. Midgley, editors. Climate change 2013: the physical science basis. Contribution of Working Group I to the Fifth Assessment Report of the Intergovernmental Panel on Climate Change. Cambridge University Press, Cambridge, UK. http://dx.doi.org/10.1017/ CBO9781107415324.028

Corbin, J. M., and A. Strauss. 1990. Grounded theory research: procedures, canons, and evaluative criteria. Qualitative Sociology 13:3-21. http://dx.doi.org/10.1007/BF00988593 
Costenbader, E., and T. W. Valente. 2003. The stability of centrality measures when networks are sampled. Social Networks 25:283-307. http://dx.doi.org/10.1016/S0378-8733(03)00012-1

Crona, B., and Ö. Bodin. 2006. What you know is who you know? Communication patterns among resource users as a prerequisite for co-management. Ecology and Society 11(2):7. [online] URL: http://www.ecologyandsociety.org/vol11/iss2/art7/

Crona, B., A. Wutich, A. Brewis, and M. Gartin. 2013. Perceptions of climate change: linking local and global perceptions through a cultural knowledge approach. Climatic Change 119:519-531. http://dx.doi.org/10.1007/s10584-013-0708-5

D'Andrade, R. G. 1987. Modal responses and cultural expertise. American Behavioral Scientist 31:194-202. http://dx.doi. org/10.1177/000276487031002005

Dorji, T., Ø. Totland, S. R. Moe, K. A. Hopping, J. Pan, and J. A. Klein. 2013. Plant functional traits mediate reproductive phenology and success in response to experimental warming and snow addition in Tibet. Global Change Biology 19:459-472. http:// dx.doi.org/10.1111/gcb.12059

Fernández-Llamazares, Á., I. Díaz-Reviriego, A. C. Luz, M. Cabeza, A. Pyhälä, V. Reyes-García. 2015. Rapid ecosystem change challenges the adaptive capacity of local environmental knowledge. Global Environmental Change 31:272-284. http://dx. doi.org/10.1016/j.gloenvcha.2015.02.001

Fernández-Giménez, M. E. 2000. The role of Mongolian nomadic pastoralists' ecological knowledge in rangeland management. Ecological Applications 10:1318-1326.

Fernández-Giménez, M. E., and F. F. Estaque. 2012. Pyrenean pastoralists' ecological knowledge: documentation and application to natural resource management and adaptation. Human Ecology 40:287-300. http://dx.doi.org/10.1007/s10745-012-9463$\underline{x}$

Fischer, A. M. 2011. The great transformation of Tibet? Rapid labor transitions in times of rapid growth in the Tibet Autonomous Region. Himalaya, the Journal of the Association for Nepal and Himalayan Studies 30(1):14.

Folke, C., F. Berkes, and J. Colding. 1998. Ecological practices and social mechanisms for building resilience and sustainability. Pages 414-436 in F. Berkes and C. Folke, editors. Linking social and ecological systems: management practices and social mechanisms for building resilience. Cambridge University Press, Cambridge, UK.

Freeman, L. C. 1978-1979. Centrality in social networks and conceptual clarification. Social Networks 1:215-239. http://dx. doi.org/10.1016/0378-8733(78)90021-7

Fu, Y., R. E. Grumbine, A. Wilkes, Y. Wang, J.-C. Xu, and Y.-P. Yang. 2012. Climate change adaptation among Tibetan pastoralists: challenges in enhancing local adaptation through policy support. Environmental Management 50:607-621. http:// dx.doi.org/10.1007/s00267-012-9918-2

Gearheard, S., M. Pocernich, R. Stewart, J. Sanguya, H. P. Huntington. 2010. Linking Inuit knowledge and meteorological station observations to understand changing wind patterns at Clyde River, Nunavut. Climatic Change 100:267-294. http://dx. doi.org/10.1007/s10584-009-9587-1
Gould, R. V., and R. M. Fernandez. 1989. Structures of mediation: a formal approach to brokerage in transaction networks. Sociological Methodology 19:89-126. http://dx.doi. org/10.2307/270949

Hanneman, R. A., and M. Riddle. 2005. Introduction to social network methods. University of California, Riverside, California, USA. [online] URL: http://www.faculty.ucr.edu/ hanneman/ nettext/

Harris, R. B. 2010. Rangeland degradation on the QinghaiTibetan plateau: a review of the evidence of its magnitude and causes. Journal of Arid Environments 74:1-12. http://dx.doi. org/10.1016/j.jaridenv.2009.06.014

Homann, S., B. Rischkowsky, J. Steinbach, M. Kirk, and E. Mathias. 2008. Towards endogenous livestock development: Borana pastoralists' responses to environmental and institutional changes. Human Ecology 36:503-520. http://dx.doi.org/10.1007/ s10745-008-9180-7

Hopkins, A. 2011. Use of network centrality measures to explain individual levels of herbal remedy cultural competence among the Yucatec Maya in Tabi, Mexico. Field Methods 23:307-328. [online] URL: http://www.ncbi.nlm.nih.gov/pubmed/21909235

Hu, J., K. A. Hopping, J. K. Bump, S. Kang, and J. A. Klein. 2013. Climate change and water use partitioning by different plant functional groups in a grassland on the Tibetan Plateau. PLoS One 8(9):e75503. http://dx.doi.org/10.1371/journal.pone.0075503

Huber, T., and P. Pedersen. 1997. Meteorological knowledge and environmental ideas in traditional and modern societies: the case of Tibet. Journal of the Royal Anthropological Institute 3:577-597. http://dx.doi.org/10.2307/3034768

Ingty, T., and K. S. Bawa. 2012. Climate change and indigenous peoples. Pages 275-290 in M. L. Arrawatia and S. Tambe, editors. Climate change in Sikkim: patterns, impacts and initiatives. Information and Public Relations Department, Government of Sikkim, Gangtok, India. [online] URL: http://www.sikkimforest. gov.in/climate-change-in-sikkim/climate $\% 20$ change $\% 20 \mathrm{in} \% 20$ sikkim $\%^{0}$ 20- $\% 20$ patterns $\% 20$ impacts $\% 20$ and $\% 20$ initiatives.htm

Isaac, M. E., L. C. N. Anglaaere, D. S. Akoto, and E. Dawoe. 2014. Migrant farmers as information brokers: agroecosystem management in the transition zone in Ghana. Ecology and Society 19(2):56. http://dx.doi.org/10.5751/es-06589-190256

Iselin, L. 2011. Modern education and changing identity constructions in Amdo. Himalaya, the Journal of the Association for Nepal and Himalayan Studies 30(1):17. [online] URL: http:// www.case.edu/affil/tibet/moreTibetInfo/documents/

ModernEducationandChangingIdentityConstructions.pdf

Kang, S., Y. Xu, Q. You, W.-A. Flügel, N. Pepin, and T. Yao. 2010. Review of climate and cyrospheric change in the Tibetan Plateau. Environmental Research Letters 5:015101. [online] URL: http:// iopscience.iop.org/article/10.1088/1748-9326/5/1/015101

Klein, J. A., J. Harte, and X.-Q. Zhao. 2007. Experimental warming, not grazing, decreases rangeland quality on the Tibetan Plateau. Ecological Applications 17:541-557. http://dx.doi. org/10.1890/05-0685

Klein, J. A., K. A. Hopping, E. T. Yeh, Y. Nyima, R. B. Boone, and K. A. Galvin. 2014. Unexpected climate impacts on the 
Tibetan Plateau: local and scientific knowledge in findings of delayed summer. Global Environmental Change 28:141-152. http:// dx.doi.org/10.1016/j.gloenvcha.2014.03.007

Klein, J. A., E. Yeh, J. Bump, Y. Nyima, and K. Hopping. 2011. Coordinating environmental protection and climate change adaptation policy in resource-dependent communities: a case study from the Tibetan Plateau. Pages 423-438 in J. D. Ford and L. Berrang-Ford, editors. Climate change adaptation in developed nations: from theory to practice. Springer, New York, New York, USA. http://dx.doi.org/10.1007/978-94-007-0567-8 31

Kronik, J., and D. Verner. 2010. The role of indigenous knowledge in crafting adaptation and mitigation strategies for climate change in Latin America. Pages 145-169 in R. Mearns and A. Norton, editors. Social dimensions of climate change: equity and vulnerability in a warming world. World Bank, Washington, D.C., USA. [online] URL: https://openknowledge.worldbank.org/ handle/10986/2689

Laborde, S., J. Imberger, and S. Toussaint. 2012. Contributions of local knowledge to the physical limnology of Lake Como, Italy. Proceedings of the National Academy of Sciences 109:6441-6445. http://dx.doi.org/10.1073/pnas.1113740109

Lu, H., D. D. Cao, F. Ma, S. S. Wang, X. W. Yang, W. L. Wang, Q. W. Zhou, and B. Y. Zhao. 2014. Characterisation of locoweeds and their effect on livestock production in the western rangelands of China: a review. Rangeland Journal 36:121-131. http://dx.doi. org/10.1071/RJ13105

McCune, B., J. B. Grace, and D. L. Urban. 2002. Analysis of ecological communities. MjM Software Design, Gleneden Beach, Oregon, USA.

Miller, M. L., J. Kaneko, P. Bartram, J. Marks, and D. D. Brewer. 2004. Cultural consensus analysis and environmental anthropology: yellowfin tuna fishery management in Hawaii. Cross-Cultural Research 38:289-314. http://dx.doi. org/10.1177/1069397104264278

Naess, L. O. 2013. The role of local knowledge in adaptation to climate change. Climate Change 4:99-106. http://dx.doi. org/10.1002/wcc. 204

Ndikumana, J., J. Stuth, R. Kamidi, S. Ossiya, R. Marambii, and P. Hamlett. 2000. Coping mechanisms and their efficacy in disaster-prone pastoral systems of the Greater Horn of Africa: effects of the 1995-97 drought and the 1997-98 El Niño rains and the responses of pastoralists and livestock. International Livestock Research Institute, Nairobi, Kenya.

Nelson, G. C. 2005. Drivers of ecosystem change: summary chapter. Pages 73-76 in R. Hassan, R. Scholes, and N. Ash, editors. Millennium Ecosystem Assessment. Island, Washington, D.C., USA. [online] URL: http://www.millenniumassessment.org/ documents/document.272.aspx.pdf

O'Brien, K. L., and R. M. Leichenko. 2000. Double exposure: assessing the impacts of climate change within the context of economic globalization. Global Environmental Change 10:221-232. http://dx.doi.org/10.1016/S0959-3780(00)00021-2

Oba, G. 2012. Harnessing pastoralists' indigenous knowledge for rangeland management: three African case studies. Pastoralism: Research, Policy and Practice 2:1. http://dx.doi.org/10.1186/2041-7136-2-1
Oteros-Rozas, E., R. Ontillera-Sánchez, P. Sanosa, E. GómezBaggethun, V. Reyes-García, and J. A. González. 2013. Traditional ecological knowledge among transhumant pastoralists in Mediterranean Spain. Ecology and Society 18(3):33. http://dx. doi.org/10.5751/es-05597-180333

R Development Core Team. 2015. R: a language and environment for statistical computing. 3.2.2 ed. R Foundation for Statistical Computing, Vienna, Austria.

Reid, R. S., D. Nkedianye, M. Y. Said, D. Kaelo, M. Neselle, O. Makui, L. Onetu, S. Kiruswa, N. O. Kamuaro, P. Kristjanson, J. Ogutu, S. B. BurnSilver, M. J. Goldman, R. B. Boone, K. A. Galvin, N. M. Dickson, and W. C. Clark. 2009. Evolution of models to support community and policy action with science: balancing pastoral livelihoods and wildlife conservation in savannas of East Africa. Proceedings of the National Academy of Sciences. http://dx.doi.org/10.1073/pnas.0900313106

Reyes-García, V., J. Broesch, L. Calvet-Mir, N. Fuentes-Peláez, T. W. McDade, S. Parsa, S. Tanner, T. Huanca, W. R. Leonard, and M. R. Martínez-Rodríguez. 2009. Cultural transmission of ethnobotanical knowledge and skills: an empirical analysis from an Amerindian society. Evolution and Human Behavior 30:274-285. http://dx.doi.org/10.1016/j.evolhumbehav.2009.02.001

Reyes-García, V., E. Kightley, I. Ruiz-Mallén, N. Fuentes-Peláez, K. Demps, T. Huanca, and M. R. Martínez-Rodríguez. 2010. Schooling and local environmental knowledge: do they complement or substitute each other? International Journal of Educational Development 30:305-313. http://dx.doi.org/10.1016/ j.ijedudev.2009.11.007

Reyes-García, V., V. Vadez, T. Huanca, W. R. Leonard, and T. McDade. 2007. Economic development and local ecological knowledge: a deadlock? Quantitative research from a Native Amazonian society. Human Ecology 35:371-377. http://dx.doi. org/10.1007/s10745-006-9069-2

Romney, A. K., W. H. Batchelder, and S. C. Weller. 1987. Recent applications of cultural consensus theory. American Behavioral Scientist 31:163-177. http://dx.doi.org/10.1177/000276487031002003

Romney, A. K., S. C. Weller, and W. H. Batchelder. 1986. Culture as consensus: a theory of culture and informant accuracy. American Anthropologist 88:313-338. http://dx.doi.org/10.1525/ aa.1986.88.2.02a00020

Salick, J., A. Byg, and K. Bauer. 2012. Contemporary Tibetan cosmology of climate change. Journal for the Study of Religion, Nature and Culture 6:447-476. http://dx.doi.org/10.1558/jsrnc. v6i4.447

Salick, J., and N. Ross. 2009. Traditional peoples and climate change. Global Environmental Change 19:137-139. http://dx.doi. org/10.1016/j.gloenvcha.2009.01.004

Sasovova, Z., A. Mehra, S. P. Borgatti, and M. C. Schippers. 2010. Network churn: the effects of self-monitoring personality on brokerage dynamics. Administrative Science Quarterly 55:639-670. http://dx.doi.org/10.2189/asqu.2010.55.4.639

Shen, M., S. Piao, N. Cong, G. Zhang, and I. A. Jassens. 2015. Precipitation impacts on vegetation spring phenology on the Tibetan Plateau. Global Change Biology 21:3647-3656. http://dx. doi.org/10.1111/gcb.12961 
Shi, Y., Y. Wang, Y. Ma, W. Ma, C. Liang, D. F. B. Flynn, B. Schmid, J. Fang, and J.-S. He. 2014. Field-based observations of regional-scale, temporal variation in net primary production in Tibetan alpine grasslands. Biogeosciences 11:2003-2016. http:// dx.doi.org/10.5194/bg-11-2003-2014

Smith, H. A., and K. Sharp. 2012. Indigenous climate knowledges. Climate Change 3:467-476. http://dx.doi.org/10.1002/wcc.185

Sternberg, R. J., C. Nokes, P. W. Geissler, R. Prince, F. Okatcha, D. A. Bundy, and E. L. Girgorenko. 2001. The relationship between academic and practical intelligence: a case study in Kenya. Intelligence 29:401-418. http://dx.doi.org/10.1016/ $\underline{\text { S0160-2896(01)00065-4 }}$

Strauss, A., and J. M. Corbin. 1998. Basics of qualitative research: techniques and procedures for developing grounded theory. Second edition. Sage, Thousands Oaks, California, USA.

Strauss, S., and B. S. Orlove. 2003. Weather, climate, culture. Berg, Oxford, UK.

Thébault, A., P. Mariotte, C. J. Lortie, and A. S. MacDougall. 2014. Land management trumps the effects of climate change and elevated $\mathrm{CO} 2$ on grassland functioning. Journal of Ecology 102:896-904. http://dx.doi.org/10.1111/1365-2745.12236

Unteregelsbacher, S., S. Hafner, G. Guggenberger, G. Miehe, X. Xu, J. Liu, and Y. Kuzyakov. 2012. Response of long-, mediumand short-term processes of the carbon budget to overgrazinginduced crusts in the Tibetan Plateau. Biogeochemistry 111:187-201. http://dx.doi.org/10.1007/s10533-011-9632-9

Wang, S., J. Duan, G. Xu, Y. Wang, Z. Zhang, Y. Rui, C. Luo, B. $\mathrm{Xu}, \mathrm{X}$. Zhu, X. Chang, X. Cui, H. Niu, X. Zhao, and W. Wang. 2012. Effects of warming and grazing on soil $\mathrm{N}$ availability, species composition, and ANPP in an alpine meadow. Ecology 93:2365-2376. http://dx.doi.org/10.1890/11-1408.1

Weller, S. C. 2007. Cultural consensus theory: applications and frequently asked questions. Field Methods 19:339-368. http://dx. doi.org/10.1177/1525822X07303502

Wickham, H. 2009. Ggplot2: elegant graphics for data analysis. Springer, New York, New York, USA.

Yangzong, C. 2006. The household responsibility contract system and the question of grassland protection: a case study from the Chang Tang, northwest Tibet Autonomous Region. Thesis. University of Tromso, Tromso, Norway. [online] URL: http:// www.case.edu/affil/tibet/tibetanNomads/documents/ TheHouseholdresponsibilitycontractsystemandthequestionofgrasslandprotection.pdf

Yeh, E. T., Y. Nyima, K. A. Hopping, and J. A. Klein. 2014. Tibetan pastoralists' vulnerability to climate change: a political ecology analysis of snowstorm coping capacity. Human Ecology 42:61-74. http://dx.doi.org/10.1007/s10745-013-9625-5

Yu, H., E. Luedeling, and J. Xu. 2010. Winter and spring warming result in delayed spring phenology on the Tibetan Plateau. Proceedings of the National Academy of Sciences 107:22151-22156. http://dx.doi.org/10.1073/pnas. 1012490107
Zarger, R. K., and J. R. Stepp. 2004. Persistence of botanical knowledge among Tzeltal Maya children. Current Anthropology 45:413-418. http://dx.doi.org/10.1086/420908

Zent, S. 1999. The quandary of ethnoecological knowledge: a Piaroa example. Pages 90-124 in T. L. Gragson and B. G. Blount, editors. Ethnoecology: knowledge, resources, and rights. University of Georgia Press, Athens, Georgia, USA.

Zhang, G., H. Xie, S. Kang, D. Yi, and S. F. Ackley. 2011. Monitoring lake level changes on the Tibetan Plateau using ICESat altimetry data (2003-2009). Remote Sensing of Environment 115:1733-1742. http://dx.doi.org/10.1016/j.rse.2011.03.005

Zhang, G., Y. Zhang, J. Dong, and X. Xiao. 2013. Green-up dates in the Tibetan Plateau have continuously advanced from 1982 to 2011. Proceedings of the National Academy of Sciences 110:4309-4314. http://dx.doi.org/10.1073/pnas.1210423110

Zhang, J., Q. Chang, and F. Yao. 2015. Grassland phenology in different eco-geographic regions over the Tibetan Plateau. International Journal of Environmental, Chemical, Ecological, Geological and Geophysical Engineering 9:964-969. [online] URL: http://waset.org/publications/10002213/grassland-phenology-in-differenteco-geographic-regions-over-the-tibetan-plateau 


\section{Appendix 1}

Table A1.1. Codes used for qualitative analysis of environmental knowledge and drivers of environmental change. Groundedness indicates how many times each code was applied throughout all interviews, and density indicates the frequency with which they co-occurred with other codes. Personal observations were often implied throughout interviews, but this code was only applied to explicit references to personal observations of phenomena. "Cosmological" explanations are related to the resource management family of codes because of the way that they causally link human behavior and environmental conditions.

\begin{tabular}{|c|c|c|}
\hline Code & Groundedness & Co-occurring codes (density) \\
\hline \multicolumn{3}{|l|}{ CLIMATE } \\
\hline Rain & 83 & $\begin{array}{l}\text { Meadows (31), Wetlands (17), Livestock (15), } \\
\text { Traditional knowledge (13), Snow (9), Lichen (7), Toxic } \\
\text { plants (6), Temperature (5), Lake (4), Learning (4), } \\
\text { Weather (4), Mountains (2), Personal observation (2), } \\
\text { Shrubs (2), Soil (2), Fences (1), Teaching (1) }\end{array}$ \\
\hline $\begin{array}{l}\text { Snow } \\
\text { (mostly severe } \\
\text { snowstorms) }\end{array}$ & 66 & $\begin{array}{l}\text { Mobility (27), Livestock (24), Meadows (14), } \\
\text { Traditional knowledge (12), Rain (9), Wetlands (7), } \\
\text { Weather (6), Learning (2), Personal observation (2), } \\
\text { Fences (1), Teaching (1), Temperature (1), Toxic plants } \\
\text { (1), Village leaders (1) }\end{array}$ \\
\hline Temperature & 25 & $\begin{array}{l}\text { Mountains (14), Lake (9), Rain (5), Traditional } \\
\text { knowledge (4), Personal observation (3), Learning (2), } \\
\text { Livestock (2), Meadows (2), Snow (1), Wetlands (1) }\end{array}$ \\
\hline Weather & 109 & $\begin{array}{l}\text { Meadows (56), Livestock (24), Wetlands (18), Men (9), } \\
\text { Traditional knowledge (9), Snow (6), Rain (4), Shrubs } \\
\text { (4), Toxic plants (4), Fences (3), Conflict (2), Learning } \\
\text { (2), Mobility (2), Mountains (2), Village leaders (2), } \\
\text { Women (2), Lake (1), Lichen (1), Teaching (1) }\end{array}$ \\
\hline \multicolumn{3}{|r|}{ (1) } \\
\hline Ice & 3 & Lake (3) \\
\hline Lake & 49 & $\begin{array}{l}\text { Mountains (10), Temperature (9), Rain (4), Wetlands } \\
\text { (4), Ice (3), Meadows (3), Cosmology (2), Livestock } \\
\text { (2), Personal observation (2), Mobility (1), Village } \\
\text { leaders (1), Weather (1) }\end{array}$ \\
\hline $\begin{array}{l}\text { Mountains } \\
\text { ("snow } \\
\text { mountains") }\end{array}$ & 34 & $\begin{array}{l}\text { Temperature (14), Lake (10), Personal observation (3), } \\
\text { Rain (2), Weather (2), Cosmology (1), Meadows (1) }\end{array}$ \\
\hline Wetlands & 88 & $\begin{array}{l}\text { Learning (26), Meadows (24), Livestock (18), Weather } \\
\text { (18), Rain (17), Fences (10), Personal observation (7), } \\
\text { Snow (7), Lake (4), Conflict (3), Mobility (3), Toxic } \\
\text { plants (3), Village leaders (3), Cosmology (2), Soil (2), } \\
\text { Lichen (1), Traditional knowledge (1), Temperature (1) }\end{array}$ \\
\hline
\end{tabular}


Meadows

Toxic plants

52

(Oxytropis)

Lichen

12

Shrubs

10

Soil

3

RESOURCE

MANAGEMENT

Conflict

Fences

Livestock

169

Mobility

75

Village leaders

24

Cosmology

KNOWLEDGE

Formal

education

152
Weather (56), Livestock (42), Rain (31), Learning (25), Wetlands (24), Fences (16), Snow (14), Mobility (10), Personal observation (10), Men (9), Conflict (4), Lichen (4), Traditional knowledge (4), Lake (3), Soil (3), Toxic plants (3), Temperature (2), Village leaders (2), Women (2), Cosmology (1), Mountains (1), Shrubs (1) Learning (20), Livestock (13), Rain (6), Personal observation (4), Weather (4), Meadows (3), Wetlands (3), Mobility (1), Snow (1), Traditional knowledge (1) Rain (7), Meadows (4), Cosmology (1), Livestock (1), Soil (1), Weather (1), Wetlands (1)

Weather (4), Rain (2), Learning (1), Meadows (1), Personal observation (1)

Livestock (3), Meadows (3), Rain (2), Wetlands (2), Cosmology (1), Learning (1), Lichen (1), Traditional knowledge (1)

Fences (19), Livestock (9), Mobility (5), Meadows (4), Wetland (3), Weather (2)

Livestock (36), Mobility (23), Conflict (19), Meadow (15), Wetlands (10), Weather (3), Village leaders (2), Traditional knowledge (1), Learning (1), Rain (1), Snow (1)

Meadows (42), Fences (36), Mobility (31), Snow (24), Weather (24), Wetlands (18), Rain (15), Toxic plants (13), Women (11), Conflict (9), Men (9), Village leaders (8), Learning (6), Traditional knowledge (5), Personal observation (4), Cosmology (3), Soil (3), Lake (2), Temperature (2), Lichen (1) Livestock (31), Snow (27), Fences (23), Meadow (10), Conflict (5), Traditional knowledge (4), Village leaders (4), Wetlands (3), Learning (2), Weather (2), Lake (1), Toxic plants (1)

Livestock (8), Mobility (4), Wetlands (3), Fences (2), Traditional knowledge (1), Lake (1), Meadows (2), Weather (2), Snow (1)

Livestock (3), Lake (2), Wetlands (2), Learning (1), Lichen (1), Meadows (1), Mountains (1), Personal observation (1), Soil (1), Traditional knowledge (1)

Traditional knowledge (2), Learning (1), Personal observation (1), Teaching (2), Women (1) 
Traditional $\quad 46$

knowledge

Learning from 55

others

Teaching others 10

Personal

observation

Men

Women
19
Learning (16), Rain (13), Snow (12), Weather (9), Livestock (5), Meadows (4), Mobility (4), Teaching (4), Temperature (4), Personal observation (3), Formal education (2), Cosmology (1), Fences (1), Men (1), Soil (1), Toxic plants (1), Village leaders (1), Wetlands (1), Women (1)

Wetlands (26), Meadows (25), Toxic plants (20), Traditional knowledge (16), Livestock (6), Personal observation (6), Teaching (6), Rain (4), Formal education (2), Mobility (2), Snow (2), Temperature (2), Weather (2), Cosmology (1), Fences (1), Shrubs (1), Soil (1)

Learning (5), Traditional knowledge (4), Personal observation (3), Meadows (2), Weather (2), Formal education (1), Livestock (1), Men (1), Rain (1), Snow (1), Toxic plants (1), Wetlands (1), Women (1) Meadows (11), Wetlands (7), Learning (6), Livestock (5), Toxic plants (4), Mountains (3), Teaching (3), Temperature (3), Traditional knowledge (3), Lake (2), Rain (2), Snow (2), Cosmology (1), Formal education (1), Shrubs (1), Men (1), Weather (1), Women (1) Livestock (9), Meadows (9), Weather (9), Women (2), Formal education (1), Personal observation (1), Traditional knowledge (1), Teaching (1) Livestock (11), Meadows (2), Weather (2), Men (2), Formal education (1), Personal observation (1), Traditional knowledge (1), Teaching (1) 